\title{
Directional Asymmetry of Morphological Traits During Postnatal Ontogeny \\ in Root Vole Microtus oeconomus Pall. (Rodentia, Cricetidae)
}

\author{
Vera Yu. Kovaleva ${ }^{\text {a* }}$, \\ Vadim M. Efimov ${ }^{a, b, c}$ and Yuri N. Litvinov ${ }^{a}$ \\ ${ }^{a}$ Institute of Systematics and Ecology of Animals SB RAS, \\ 11 Frunze Str., Novosibirsk, Russia 630091 \\ ${ }^{b}$ Institute of Cytology and Genetics SB RAS, \\ 10 Pr. Lavrentyeva, Novosibirsk, Russia 630090 \\ 'Tomsk State University, \\ 36 Pr. Lenina, Tomsk, Russia 634050
}

Received 05.11.2012, received in revised form 22.11.2012, accepted 19.05.2013

We analyzed Microtus oeconomus material collected for 25 years (1982-1992, 1994-2005, 2009, 2010). Directional asymmetry (DA) was demonstrated for teeth morphotypes, adrenal and kidney weights, and for length of the hind paw as well. DA may be formed both at early and later development stages and is not dependent on environmental factors and population density dynamics. Although each trait has its own dynamics DA in ontogeny, usually DA increases in the period of sexual maturation. Uncoordinated development of the sides in this period seems to associate with an increase in intensity of developmental processes. Our study argues that sexual dimorphism of continuous traits appears at the later developmental stages. This finding is consistent with Geodakian's evolutionary theory of sex. Evolutionary significance of the DA is to increase both short-term individual fitness and long-term population adaptive capacity. Developmental approach to the study of morphological and functional asymmetries in animals opens new possibilities for the study of evolutionary processes.

Keywords: Microtus oeconomus, directional asymmetry, teeth morphotypes, adrenal and kidney weights, paw lengths, environmental conditions, population density dynamics.

(C) Siberian Federal University. All rights reserved

* Corresponding author E-mail address: vkova@ngs.ru 


\section{Introduction}

In recent decades, the study of asymmetry in zoology has been reduced to fluctuating asymmetry as an indicator of stability of individual development and/or quality of the natural environment (Zakharov, Graham 1992; Parsons 1992; Palmer, Strobeck, 1992, 2003; Clarke, 1993; Leung et al., 2000; Zakharov, 2003; Van Dongen, 2006). Directional asymmetry (DA) and antisymmetry were more often regarded as nuisance safer to omit from estimation of fluctuating asymmetry (Graham et al., 1998; Stige et al., 2006). Nevertheless, DA of bilateral traits is widespread in nature, most likely inherent in most animal species (Levin, Palmer, 2007; Palmer, 2009).

The impetus for rapid research in the field of DA came from the finding of asymmetrically expressing genes in early development, such as Shh and Nodal in chicken (Levin et al., 1995) and Nodal and Leftyl in mice (Collignon et al., 1996; Lowe et al., 1996; Meno et al., 1998). It is known that numerous genes are involved in patterning left-right visceral asymmetry (Shiratori, Hamada, 2006). That DA has a genetic basis is a fact beyond question. It is of relevance that early ontogeny only, when the primordial structures are laid down, have been so far studied (LopezGracia, Ros, 2007).

It is known that there are genes and their aggregates that are differentially expressed at particular developmental stages (DS) (Zahn et al., 2007). Therefore, we can assume that it is true for DA also, i.e. leading to the DA corresponding gene network can work at each late DS. In wild populations, such networks must pass through natural selection and their effects should be manifested at the phenotypic level. Hence, the aim of our research is to study both discrete and continuous traits bilateral DA depending on sex, DS, environmental conditions and population density dynamics in wild populations of animals.

\section{Materials and Methods}

Data collection

and morphometric measurements

This study was performed in Gorno-Altai region, at the northern shore of the lake Teletskoye, in the site where the Institute's biological station is located $\left(51^{\circ} 47^{\prime} 34^{\prime \prime} \mathrm{N}, 8^{\circ} 16^{\prime} 33^{\prime \prime}\right.$ E). Voles were wild-caught in the vicinities of the station, in terraces around the lake. Many years of observations on the dynamics of a community of wild mouselike rodents inhabiting near the station showed that the root vole (Microtus oeconomus) and the northern red-backed vole (Myodes rutilus $=$ Clethrionomys rutilus) prevail among vole species (Litvinov et al., 2006).

Here we analyzed the root vole material collected for 25 years (1982-1992, 1994-2005, 2009, 2010). Root vole populations fluctuate in cycles with a 3-4 year periodicity (Fig. 1A). In addition, there is a long-term trend of population density, possibly associated with an increase in average annual temperature (Fig. 1B).

Specimens were analyzed for bilateral morphotypic variation in first lower molar $\mathrm{M}_{1}$ $(\mathrm{N}=707)$ and the third upper molar $\mathrm{M}^{3}(\mathrm{~N}=709)$ teeth. To discriminate between different morphotypes, we used the number of closed triangles on chewing surface and the shape complexity of the labial and lingual sides of the anterior unpaired loop of $\mathrm{M}_{1}$ and talon of $\mathrm{M}^{3}$ (Pozdnyakov, 1993; Kovaleva et al., 2002). On this basis, morphotype complexity (MC) was calculated for each of the morphotypes (Fig. 2). In addition, morphotype complexity asymmetry $d_{R-L}$ was calculated for each of the specimens as follow (Pozdnyakov, 2010):

$$
\mathrm{d}_{\mathrm{R}-\mathrm{L}}=\mathrm{MC}(\text { right })-\mathrm{MC}(\text { left })
$$

Measurements of metric traits were taken exclusively by one of the authors (VYuK). The excised left and right kidneys and adrenals were 

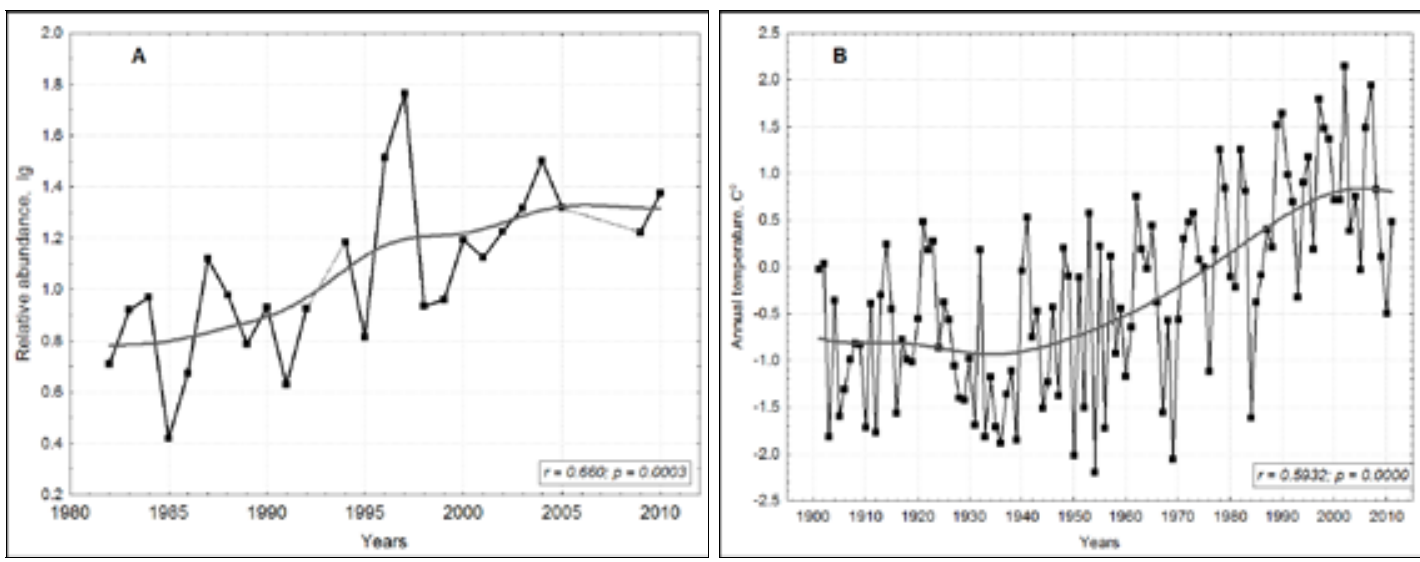

Fig. 1. A) Microtus oeconomus relative abundance dynamic (per 100 trap-nights, lg); B) Average annual temperature dynamic (Ongudai meteorological station), gray curve - distance weighted least squares fitting

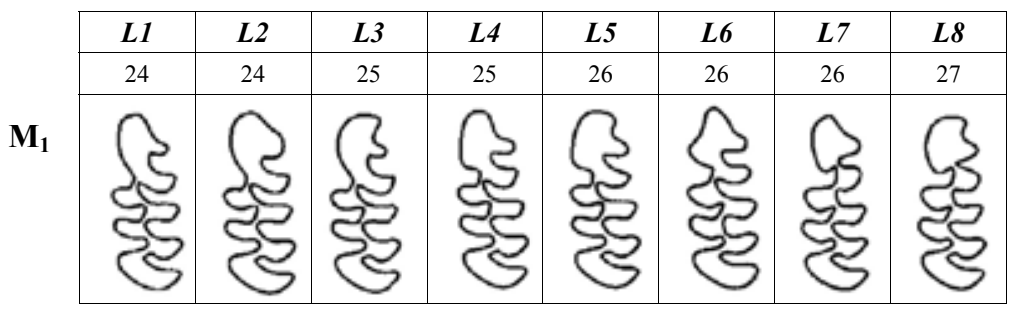

\begin{tabular}{|c|c|c|c|c|c|c|c|c|c|c|}
\hline$L 1$ & $L 2$ & $L 3$ & $L 4$ & $L 5$ & $L 6$ & $L 7$ & $L 8$ & $L 9$ & $L 10$ & $L 11$ \\
\hline 11 & 12 & 12 & 12 & 13 & 13 & 13 & 14 & 14 & 14 & 15 \\
\hline & & & & & & & & & & \\
\hline
\end{tabular}

Fig. 2. Microtus oeconomus morphotypic variation in chewing surface of the first lower $\left(\mathrm{M}_{1}\right)$ and the third upper molar $\left(\mathrm{M}^{3}\right)$. Morphotype complexity values are given under each morphotype designation. (Outlines are made by A.A. Pozdnyakov)

weighed with a torsion balance to a precision of $1 \mathrm{mg}$. It is very important to reduce measurement errors in asymmetry studies, since the difference between the bilateral traits is usually small (Palmer, Strobeck, 1986; Palmer, 1994; Merilä, Björklund, 1995). For this reason, the lengths of the external morphometric traits, the front and hind paw, were measured 2-3 times with a caliper $0.1 \mathrm{~mm}$ to reduce measurement errors. If the difference between the measures was larger than $0.3 \mathrm{~mm}$, measurements were repeated. The median, i.e. the non-parametric point estimate, was chosen.

The relative age of voles was estimated according to the degree of physiological maturation and the data on body length and mass by the standard methods (Bashenina, 1953; Larina, Lapshov, 1974). According to this, all voles were divided into four age groups: immature, juveniles and subadults, and mature, adults and senescents. 
Males and females were analyzed separately. Morphotypes variability showed no particular relation to age and sex, therefore we considered all sets as a pooled sample containing more than 700 molar pairs.

\section{Statistical analysis}

The correlation coefficient between $d_{R-L}$ for $\mathrm{M}_{1}$ and $\mathrm{M}^{3}$ was calculated. Then, we calculated contingency tables between right-side and leftside both $\mathrm{M}_{1}$ and $\mathrm{M}^{3}$ morphotypes. Morphotypes observed fewer than 8 times, were excluded from further analysis.

All metric traits were $\log$ transformed (Graham et al., 2003; Palmer, Strobeck, 2003). The significance of the presence of DA in every sample was tested using Student's paired $t$-test (Palmer, 1994).

The following values were assigned to each specimen to calculate the correlation with DS, environmental conditions and population parameters: Year - trapping year; Trapping date - number of calendar days from the 1th May of the trapping year to the trapping day; Sexual maturity -0 for immature voles, 1 for mature ones; Abundance dynamic (AD): AD - number of captures per 100 trap-nights in trapping year, $\mathrm{lg} ; \mathrm{AD}_{\mathrm{dev}}-\mathrm{AD}$ deviation from regression line; $\mathrm{AD}_{\text {abs(dev) - absolute deviation from regression }}$ line; $\mathrm{T}_{\text {May }}, \mathrm{T}_{\text {Jun }}, \mathrm{T}_{\text {Jul }}, \mathrm{T}_{\text {Aug }}$ - average monthly temperatures in May, June, July and August, accordingly. We included the $\mathrm{AD}_{\text {dev }}$ and $\mathrm{AD}_{\mathrm{abs}(\mathrm{dev})}$ parameters in the calculation in order to take into account the possible dependence between $\mathrm{AD}$ deviations from population norm in the direction of higher or lower density and DA. The population norm was itself increased during the period of our studies (Fig. 1).

DA, although it is an individual property, can only be estimated for a group of individuals, therefore either age-independent qualitative traits or homogeneous samples composed of size-age matched individuals were used. In the case of quantitative traits, samples collected from natural populations are, as a rule, heterogeneous. Clearly, then, the difference between left and right sides of traits depends on size, which, as a rule, increases in the course of individual development. It is a convention to reduce sizeage heterogeneity by transformation of metric traits to natural logarithms (Graham et al., 1998; Graham et al., 2003; Palmer, Strobeck, 2003). A Box-Whiskers plot was applied to estimate DA variability within each age group for continuous traits. Kruskal-Wallis test and ANOVA (F test) were used to evaluate significance of DA dynamic.

\section{Results}

First, we investigated the bilateral asymmetry of discrete traits. Asymmetry of shape of $\mathrm{M}_{1}$ and $\mathrm{M}^{3}$ was the most obvious among discrete traits. No correlation between $d_{R-L}$ for $M_{1}$ and $M^{3}$ was found $(\mathrm{r}=0.0253 ; \mathrm{n}=711)$.

As expected, most of morphotype pairs turned out to be symmetrical, with asymmetrical pairs accounting for $29 \%$ and $25 \%$ of the total number of pairs of $\mathrm{M}_{1}$ and $\mathrm{M}^{3}$, respectively (Table 1, 2). Absolute value of $d_{R-L},\left|d_{R-L}\right|$, did not usually exceed 1 , sometimes reaching 2 ( $\mathrm{n}=10$ for $\mathrm{M}_{1}$ and $\mathrm{n}=13$ for $\mathrm{M}^{3}$ ) (Fig. 3A, B).

The morphotypes in the contingency tables are ordered according to their complexity. More complex morphotypes of the $\mathrm{M}_{1}$ and $\mathrm{M}^{3}$ significantly developed more often on the right side (Fig. 3A, B). Consequently, there was a DA in morphotype complexity.

Three of the four investigated continuous traits showed a DA (Table 3 ), which did not depend on environmental temperatures, population dynamics and trapping seasons for both sexes unlike an individual size (Table 4). Nevertheless, asymmetry can depend not only on trait size as such, but also on the DS of an individual. 
Table 1. Contingency table between right- and left-sides morphotypes $\mathrm{M}_{1}$ of Microtus oeconomus voles in Teletskaya population. The morphotypes (1-8) are ordered according to morphotype complexity (MC). Frequencies of symmetrical morphotype pairs are along the diagonal $(n=502)$

\begin{tabular}{|c|c|c|c|c|c|c|c|c|c|}
\hline $\operatorname{MC}\left(\mathrm{M}_{1}\right)$ & 24 & 24 & 25 & 25 & 26 & 26 & 26 & 27 & \\
\hline & L1 & L2 & L3 & L4 & L5 & L6 & L7 & L8 & Total \\
\hline $\mathrm{R} 1$ & $\underline{190}$ & 0 & 3 & 33 & 0 & 0 & 1 & 0 & 227 \\
\hline $\mathrm{R} 2$ & 0 & $\underline{\mathbf{3}}$ & 0 & 0 & 0 & 0 & 0 & 0 & 3 \\
\hline R3 & 12 & 0 & $\underline{18}$ & 2 & 3 & 0 & 0 & 0 & 35 \\
\hline $\mathrm{R} 4$ & 85 & 2 & 1 & $\underline{244}$ & 1 & 0 & 4 & 0 & 337 \\
\hline R5 & 4 & 0 & 9 & 17 & $\underline{25}$ & 0 & 3 & 1 & 59 \\
\hline R6 & 2 & 0 & 0 & 5 & 0 & $\underline{4}$ & 0 & 0 & 11 \\
\hline R7 & 2 & 0 & 0 & 11 & 1 & 0 & $\underline{16}$ & 0 & 30 \\
\hline $\mathrm{R} 8$ & 0 & 0 & 0 & 1 & 1 & 0 & 1 & $\underline{2}$ & 5 \\
\hline Total & 295 & 5 & 31 & 313 & 31 & 4 & 25 & 3 & 707 \\
\hline
\end{tabular}

Table 2. Contingency table between right- and left-sides morphotypes $\mathrm{M}^{3}$ of Microtus oeconomus voles in Teletskaya population. The morphotypes (1-11) are ordered according to morphotype complexity (MC) (11-15). Frequencies of symmetrical morphotype pairs are along the diagonal $(n=530)$

\begin{tabular}{|c|ccccccccccc|c|}
\hline $\begin{array}{c}\text { MC } \\
\left(\mathrm{M}^{3}\right)\end{array}$ & 11 & 12 & 12 & 12 & 13 & 13 & 13 & 14 & 14 & 14 & 15 & \\
\hline & L1 & L2 & L3 & L4 & L5 & L6 & L7 & L8 & L9 & L10 & L11 & Total \\
\hline R1 & $\underline{\mathbf{1 4}}$ & 1 & 2 & 5 & 0 & 0 & 0 & 0 & 0 & 0 & 0 & 22 \\
R2 & 0 & $\underline{4}$ & 0 & 0 & 0 & 1 & 1 & 0 & 0 & 0 & 0 & 6 \\
R3 & 1 & 0 & $\underline{4}$ & 1 & 1 & 0 & 0 & 0 & 0 & 0 & 0 & 7 \\
R4 & 7 & 0 & 0 & $\underline{\mathbf{3 1 2}}$ & 0 & 8 & 24 & 4 & 1 & 1 & 0 & 357 \\
R5 & 0 & 1 & 0 & 0 & $\underline{4}$ & 0 & 0 & 1 & 0 & 0 & 0 & 6 \\
R6 & 0 & 1 & 0 & 16 & 0 & $\underline{\mathbf{3 8}}$ & 2 & 11 & 0 & 0 & 0 & 68 \\
R7 & 1 & 0 & 0 & 48 & 1 & 3 & $\underline{\mathbf{9 8}}$ & 4 & 2 & 0 & 0 & 157 \\
R8 & 0 & 0 & 0 & 5 & 0 & 10 & 8 & $\underline{\mathbf{4 5}}$ & 0 & 0 & 2 & 70 \\
R9 & 0 & 0 & 0 & 0 & 0 & 1 & 1 & 0 & $\mathbf{6}$ & 0 & 0 & 8 \\
R10 & 0 & 0 & 0 & 0 & 0 & 0 & 1 & 0 & 0 & $\underline{\mathbf{3}}$ & 0 & 4 \\
R11 & 0 & 0 & 0 & 0 & 0 & 0 & 1 & 1 & 0 & 0 & $\underline{\mathbf{2}}$ & 4 \\
\hline Total & 23 & 7 & 6 & 387 & 6 & 61 & 136 & 66 & 9 & 4 & 4 & 709 \\
\hline
\end{tabular}

Asymmetry for adrenal weight steadily increased in the course of development both in males and females. The average adrenal weight and maximum difference between the left and right sides of this trait reached greater values in females compared to males (Fig. 4).
The right-side DA for kidney weight was significant in males and in females, and it also depended on DS. There was a maximum for dextral kidney asymmetry before sexual maturation. The end stages of population ontogeny were characterized by symmetry of these paired organs (Fig. 5). 

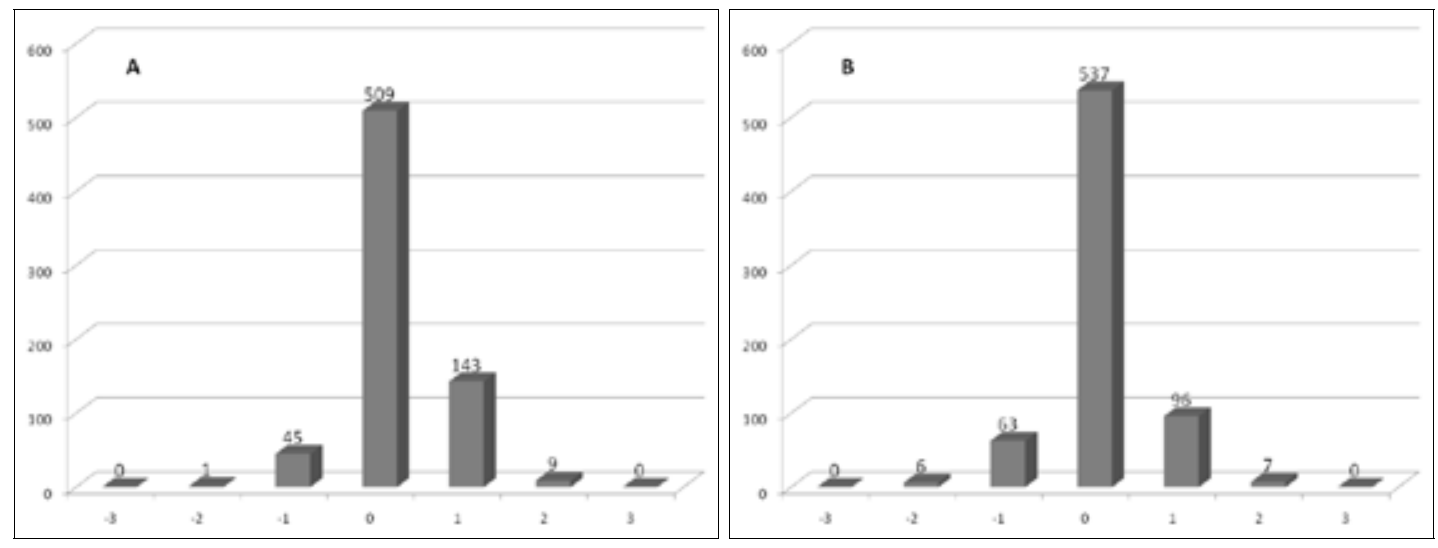

Fig. 3. Histogram of the distribution of morphotypes complexity asymmetry $\mathrm{d}_{\mathrm{R}-\mathrm{L}}$ among Microtus oeconomus specimens in Teletskaya population; A) $M_{1}$; B) $M^{3}$. Zero value of $d_{R-L}$ (the biggest columns) can appear $n$ for specimens with symmetrical morphotypes, and also for ones with asymmetric morphotypes, but with the same complexity ( $\mathrm{n}=7$ for each tooth). Specimens with nonzero values of $\mathrm{d}_{\mathrm{R}-\mathrm{L}}$ anytime have asymmetric morphotypes. Mean of morphotypes complexity asymmetry $d_{R-L}$ is significantly greater than zero for both teeth $\left(M_{1}: t=7.874\right.$; $\left.\mathrm{p}<0.001 ; \mathrm{M}^{3}: \mathrm{t}=2.419 ; \mathrm{p}=0.015\right)$. Abscissa $-\mathrm{d}_{\mathrm{R}-\mathrm{L}}$, ordinate - the number of specimens

Table 3. Statistical parameters of DA of morphological traits in samples of Microtus oeconomus voles in Teletskaya population

\begin{tabular}{ccccc}
\hline \multirow{1}{*}{ Trait } & Sex & $N$ & $\begin{array}{c}\text { Student's paired } \\
t \text {-test }\end{array}$ & $p$-value \\
\hline \multirow{2}{*}{ Adrenal weight } & Males & 623 & 12.08 & $<1^{*} 10^{-29}$ \\
& Females & 471 & 9.71 & $<1^{*} 10^{-21}$ \\
Kidney weight & Males & 524 & & $<1^{*} 10^{-8}$ \\
& Females & 384 & 9.81 & $<1^{*} 10^{-5}$ \\
Hind paw length & Males & & 4.84 & $<1^{*} 10^{-9}$ \\
& Females & 182 & 6.40 & $<1^{*} 10^{-7}$ \\
Front paw length & & & 5.76 & $>0.05$ \\
& Males & 228 & 1.93 & $>0.05$ \\
\hline
\end{tabular}

Dextral DA for the length of the hind paw was significant only in males. The right hind paw was longer than the left in young and adult voles (Fig. 6).

\section{Discussion}

It is believed that the progressive evolution of the animal kingdom is accompanied by a natural loss of symmetry (Beklemishev, 1969; Geodakian, 1991; Palmer, 2009). MCA of voles is an example of trait with incomplete evolutionary transition from symmetric to asymmetric state. The existence of asymmetry is well known and has repeatedly been observed in different rodent species (Angermann, 1973; Kovaleva et al., 2002; Vasil'ev et al., 2004; Pozdnyakov, 
Table 4. Correlation coefficients of DA (R-L) and trait size ((L+R)/2) of Microtus oeconomus voles in Teletskaya population with environmental temperatures, population dynamics and trapping date $\left({ }^{*} \mathrm{p}<0.05 ;{ }^{* *} \mathrm{p}<0.01\right.$; ${ }_{* * *}^{*} \mathrm{p}<0.001$; with Bonferroni correction), see text (Statistical analysis) for details

\begin{tabular}{|l|c|c|c|c|}
\hline \multirow{2}{*}{ Adrenal weight } & \multicolumn{2}{|c|}{ Females $(N=485)$} & \multicolumn{2}{c|}{ Males $(N=632)$} \\
\cline { 2 - 4 } & DA & Size & DA & $-0.38^{* * *}$ \\
\hline Trapping date & -0.08 & $-0.28^{* * *}$ & 0.05 & $0.77^{* * *}$ \\
Sexual maturity & $-0.21^{* * *}$ & $0.80^{* * *}$ & $-0.18^{* * *}$ & $-0.14^{*}$ \\
$\mathrm{AD}_{\text {dev }}$ & -0.11 & 0.06 & 0.04 & -0.01 \\
$\mathrm{AD}_{\text {abs(dev) }}$ & -0.08 & 0.13 & 0.01 & 0.00 \\
Year $^{*}$ & 0.02 & 0.15 & 0.03 & $-0.29^{* * *}$ \\
$\mathrm{~T}_{\text {May }}$ & -0.09 & -0.13 & 0.08 & $-0.15^{*}$ \\
$\mathrm{~T}_{\text {Jun }}$ & 0.01 & -0.07 & 0.07 & -0.10 \\
$\mathrm{~T}_{\text {Jul }}$ & -0.07 & -0.10 & -0.04 & -0.02 \\
$\mathrm{~T}_{\text {Aug }}$ & 0.03 & -0.02 & -0.05 & -0.08 \\
\hline
\end{tabular}

\begin{tabular}{|l|c|c|c|c|}
\hline \multirow{2}{*}{ Kidney weight } & \multicolumn{2}{|c|}{ Females $(N=402)$} & \multicolumn{2}{|c|}{ Males $(N=552)$} \\
\cline { 2 - 5 } & DA & Size & DA & Size \\
\hline Trapping date & 0.01 & $-0.22^{* * *}$ & 0.05 & $-0.33^{* * *}$ \\
Sexual maturity & -0.12 & $0.82^{* * *}$ & $-0.17^{* *}$ & $0.88^{* * *}$ \\
$\mathrm{AD}$ & -0.05 & $0.17^{* *}$ & 0.01 & -0.12 \\
$\mathrm{AD}$ & -0.03 & $0.21^{* * *}$ & 0.01 & -0.01 \\
$\mathrm{AD}_{\text {abs(dev) }}$ & -0.01 & $0.20^{* * *}$ & 0.05 & 0.02 \\
Year & -0.04 & -0.03 & 0.00 & $-0.27^{* * *}$ \\
$\mathrm{~T}_{\text {May }}$ & -0.04 & 0.01 & -0.02 & -0.13 \\
$\mathrm{~T}_{\text {Jun }}$ & -0.08 & -0.10 & -0.03 & $-0.22^{* * *}$ \\
$\mathrm{~T}_{\text {Jul }}$ & 0.03 & -0.07 & 0.02 & 0.01 \\
$\mathrm{~T}_{\text {Aug }}$ & -0.02 & -0.13 & -0.08 & -0.08 \\
\hline
\end{tabular}

\begin{tabular}{|l|c|c|c|c|}
\hline \multirow{2}{*}{ Hind paw length } & \multicolumn{2}{|c|}{ Females $(N=205)$} & \multicolumn{2}{|c|}{ Males $(N=257)$} \\
\cline { 2 - 4 } & DA & Size & DA & Size \\
\hline Trapping date & 0.03 & -0.01 & -0.04 & -0.12 \\
Sexual maturity & 0.05 & $0.44^{* * *}$ & 0.22 & $0.41^{* * *}$ \\
$\mathrm{AD}$ & 0.15 & 0.12 & 0.11 & 0.08 \\
$\mathrm{AD}_{\text {dev }}$ & 0.10 & 0.09 & 0.05 & $-0.28^{* *}$ \\
$\mathrm{AD}_{\text {abs(dev) }}$ & -0.08 & -0.14 & -0.16 & -0.03 \\
Year $^{*}$ & 0.16 & 0.11 & 0.14 & $-0.26^{*}$ \\
$\mathrm{~T}_{\text {May }}$ & -0.05 & -0.12 & -0.20 & 0.20 \\
$\mathrm{~T}_{\text {Jun }}$ & -0.02 & 0.06 & 0.07 & -0.13 \\
$\mathrm{~T}_{\text {Jul }}$ & -0.02 & 0.00 & -0.01 & -0.01 \\
$\mathrm{~T}_{\text {Aug }}$ & 0.09 & -0.11 & 0.00 & \\
\hline
\end{tabular}



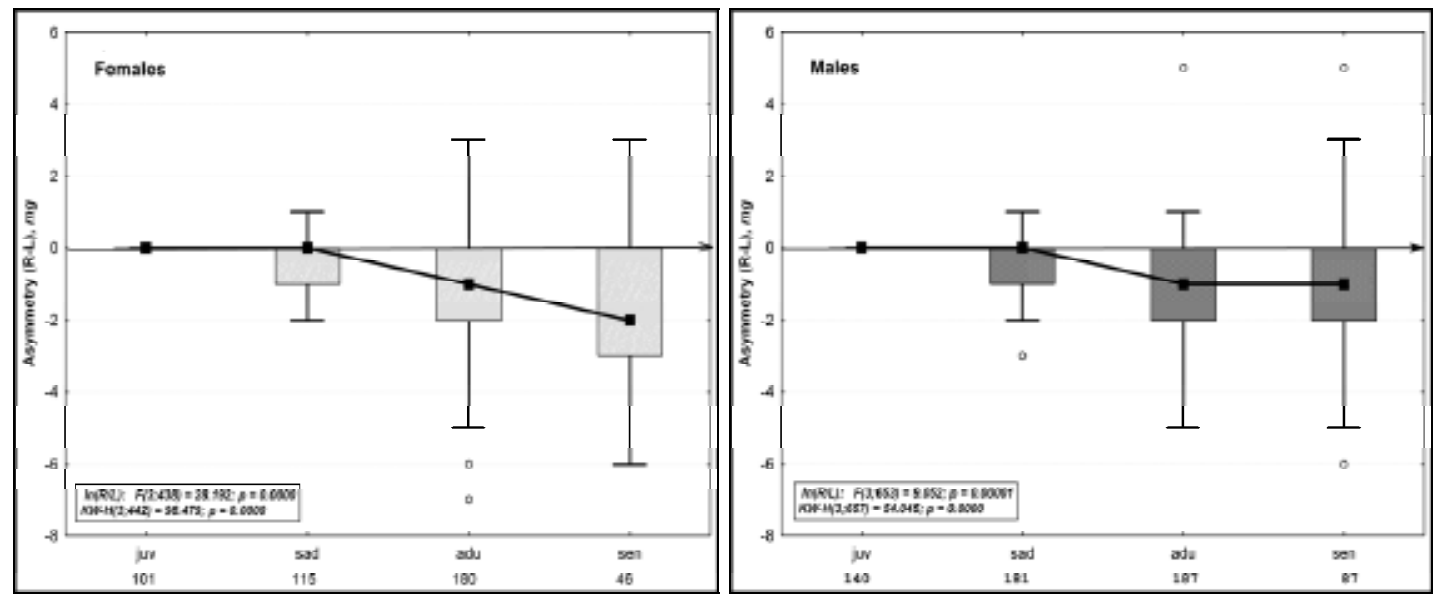

Fig 4. Age-depended dynamics of adrenal weight asymmetry of Microtus oeconomus voles in Teletskaya population. Developmental stages: juv - juveniles, sad - subadults, adu - adults, sen - senescents. The numbers under the developmental stages are age group numbers. - - median; $\square-25 \%-75 \%$; I - non-outlier range; ○outliers. F - Fisher F-test. KW-H - Kruskal-Wallis H-test
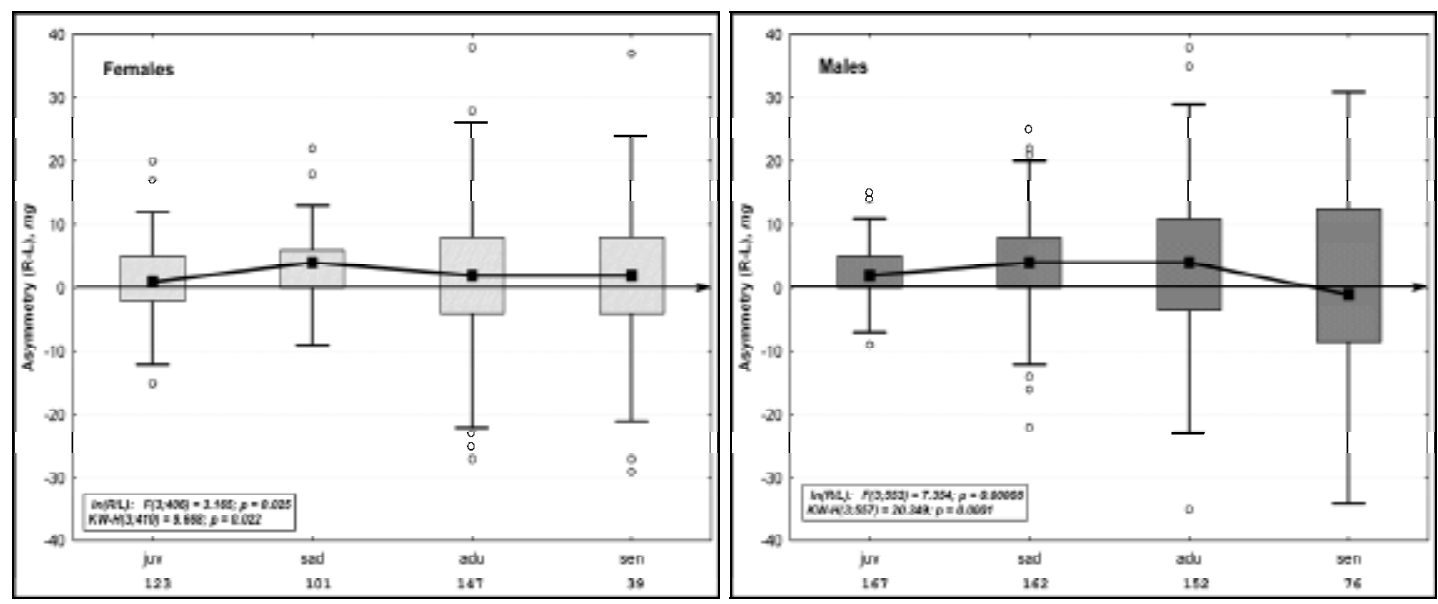

Fig 5. Age-depended dynamics of kidney weight asymmetry of Microtus oeconomus voles in Teletskaya population. For other designations, see Fig 4

2010). It is known that dental traits are highly heritable (Bader, 1965; Berry, 1975; Hlusko et al., 2011; Polly et al., 2011). In addition, the different species of the voles have a common set of morphotypes which are distinct only in frequency of occurrence (Angermann, 1973; Pozdnyakov, 2005; Pozdnyakov, 2011).

The development paths of these traits which are formed in the ancestral lines of living
Arvicolinae, are highly conservative. This is apparently based on the evolutionary stability of the trait's basic mechanisms of development which canalize all deviations (Waddington, 1942; Vasil'eva, 1999; Siegal, Bergman, 2002; Vasil'ev, 2009). Perhaps, this suggestion explains the fact that the $d_{R-L}$ in our study was small, its absolute value did not exceed 2 , and it had no developmental dynamics. 

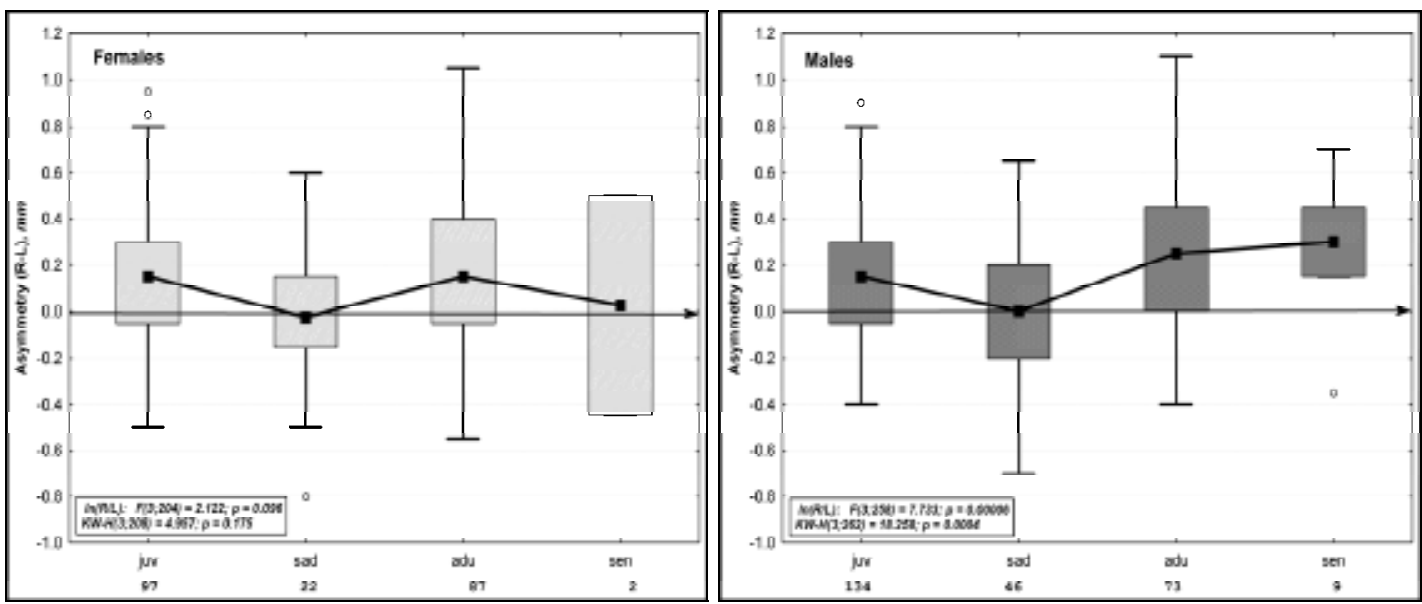

Fig 6. Age-depended dynamics of hind paw length asymmetry of Microtus oeconomus voles in Teletskaya population. For other designations, see Fig 4

According to our data, the left adrenal weighed more than the right in both sexes. The occurrence of this phenomenon among wild populations has been, to our knowledge, first described for the water vole Arvicola amphibius from Western Siberia (Galaktionov, Efimov 2003). There is a large body of laboratory data supporting this observation for other mammalian species (Idelman, 1978; Abramov et al., 1996; Coleman et al., 1998; Droste et al., 2003; Trut et al., 2002).

The founded prevalence of right asymmetry of kidney weight for the root vole is consistent with the previous reports. For instance, 7 natural populations of the house mouse caught in Great Britain, the Pacific Ocean islands, and the Subantarctica showed a statistically significant greater weight of the right kidney compared to the leftone, withdifference decreasing withincreasing kidney size and age (Berry, 1978; Mittwoch, 1979, 2008). In our view, the evolutionary implications for population ontogeny are clear: the organism strives to minimize energy expenditures under peak loads. For the growing organism, it is more advantageous to partition over time the same phases of organ growth and development at the right and the left than to go through the phases synchronously.

Asymmetry study of human limbs takes back to the nineteenth century (Arnold, 1844; Gennadis, 1858; Tarkhanov, 1879). Nonetheless, the issue of the effects of environmental and genetic factors remains very unclear. It is known that handedness is strongly correlated with hemispheric brain asymmetry, which has a considerable genetic component (Geschwind et al., 2002). The handedness-brain asymmetry relationship has been extended to primates, mammals and to some extent vertebrates as a whole (Singh, 1971; Pande, Singh 1971; Bianki, 1993). Postnatal measurements on foxes demonstrated that the DA of limb bones increases after birth and continues to change (increasing or decreasing) during postnatal growth (Kharlamova et al., 2010). Our current study revealed that most voles of the examined population have the hind version ("footedness") of this trait, rather than the front one ("handedness"). Perhaps this is due to the spatial and motor asymmetry which has been shown for many species of vertebrates (Bianki, 1993, Agulova et al., 2010; Agulova et al., 2012). 
The prevalent view of most contemporary papers is that the asymmetries in the early development stages are largely due to the contribution of internal cytogenetic factors. This is supported by the finding of specific genes responsible for establishing the body left-right axes of the vertebrate embryo. They are key components of the signaling cascade which is responsible for the formation of this axis, and also the morphological asymmetry of visceral organs (Fujunaga, 1996; Wood, 1997; Burdine, Schier, 2000). A. Palmer (1996) has suggested that the asymmetries appeared in the later stages of ontogeny are mostly due to external environmental factors.

Our studies do not support this hypothesis. Developmental dynamics of the DA of three bilateral traits did not depend on external or intrapopulation factors, despite the fact that the absolute sizes of traits are affected by a number of factors (Table 4). Similar results were obtained early (Kovaleva, Faleev, 1994).

The DA trajectories for all the set of traits before sexual maturation start are similar in males and females. This similarity allowed us to put forward the hypothesis that the two sexes have a common genetic program during its establishment in ontogeny. In the period of sexual maturation asymmetry increases and then DA trajectories of these organs are different in males and females.

Reasons for the divergence of developmental trajectories of the investigated traits are not accidental, and they are in good agreement with the Geodakian's evolutionary theory of sex (Geodakian, 1991). A trait changes only in males over many generations for diclinous forms due to replacement from stabilizing selection to moving one. Females keep the old value of trait. The trait evolution trajectory bifurcates into male and female branches. This is a divergent phase of trait evolution. Genetic sexual dimorphism arises in such a way.

\section{Conclusion}

DA of morphological traits is perhaps more widespread than it is generally thought. It may be formed both at the early and later development stages and, contrary to the Palmer' hypothesis may be not dependent on environmental factors.

Developmental approach to the study of the DA formation reveals its dynamic character. Although each trait has its own dynamics DA in ontogeny, usually DA increases in the period of sexual maturation. Uncoordinated development of the sides in this period seems to be associated with an increase in intensity of developmental processes. Our study argues that sexual dimorphism appears at the later developmental stages. Its manifestation is consistent with Geodakian's evolutionary theory of sex.

Evolutionary significance of the DA is to increase both short-term individual fitness and long-term population adaptive capacity. Developmental approach to the study of morphological and functional asymmetries in animals opens new possibilities for the study of evolutionary processes.

\section{Acknowledgments}

We thank Anna Fadeeva for translation of the manuscript from Russian into English. The work was supported by RFBR grant No.11-04-00141-a, project for Basic Research SB RAS and UB RAS 70, integration project SB RAS 18.13, the Russian President grant SS-5278.2012.4 and RAS program A.II.6. We also thank two anonymous reviewers for helping in improvement of the manuscript. 


\section{References}

1. Abramov V.V., Karmatskikh O.L., Kozlov V.A., Os'kina I.N. (1996) Functional asymmetry of adrenal glands in (CBA x C57BL/6)F1 mice. Dokl. Akad. Nauk 347(6): 831-833.

2. Agulova L.P., Andreevskikh A.V., Bolshakova N.P., Kravchenko L.B., Suchkova N.G., Moskvitina N.S. (2010) Dynamics of motor asymmetry profiles in striped field mouse (Apodemus agrarius Pall.) populations. Rus. J. Ecol. 41(6): 506-512. (in Russian)

3. Agulova L.P., Bolshakova N.P., Andreevskikh A.V., Suchkova N.G., Kravchenko L.B., Moskvitina N.S. (2012) Functional motor asymmetry in three species of mouse-like rodents from natural populations. Neurosci. Behave. Physiol. 42(7): 718-724.

4. Angermann R. (1973) Homologous variability of molars in voles (Microtinae). In: Vorontsov N.N. (ed.) Problems of evolution, vol. 3. Novosibirsk: Nauka, p. 104-118 (in Russian)

5. Arnold F. (1844) Handbuch der Anatomie des Menschen. Freiburg: Herder'sche.

6. Bader R.S. (1965) Heritability of dental characters in the house mouse. Evolution 19(3): 378384.

7. Bashenina N.V. (1953) On age determination of common vole (Microtus arvalis Pall). Rus. J. Zool. 32 (4): 730-743. (in Russian)

8. Beklemishev V.N. (1969) Principles of comparative anatomy of invertebrates. Chicago: University of Chicago Press, 1058 p.

9. Berry A.C. (1975) Factors affecting the incidence of non-metrical skeletal variants. J. Anat. 120: 519-535.

10. Berry R.J. (1978) Genetic variation in wild house mice: where natural selection and history meet. Am. Sci. 66: 52-60.

11. Bianki V.L. (1993) The mechanisms of brain lateralization. New York-London: Gordon Breach, $290 \mathrm{p}$.

12. Burdine R.D., Schier A.F. (2000) Conserved and divergent mechanisms in left-right axis formation. Genes Dev. 14: 763-776.

13. Clarke G.M. (1993) Fluctuating asymmetry of invertebrate populations as a biological indicator of environmental quality. Environ. Pollut. 82: 207-211.

14. Coleman M.A., Garland J.T., Marler C.A., Newton S.S., Swallow J.G., Carter P.A. (1998) Glucocorticoid response to forced exercise in laboratory house mice (Mus domesticus). Physiol. Behav. 63: 279-285.

15. Collignon J., Varlet I., Robertson E.J. (1996) Relationship between asymmetric nodal expression and the direction of embryonic turning. Nature 381: 155-158.

16. Droste S.K., Gesing A., Ulbricht S., Möller M.B., Linthorst A.C.E., Reul J.M.H.M. (2003) Effects of long-term voluntary exercise on the mouse hypothalamic-pituitary-adrenocortical axis. Endocrinology 144(7): 3012-3023.

17. Fujinaga M. (1997) Development of sidedness of asymmetric body structures in vertebrates. Int. J. Dev. Biol. 41: 153-186.

18. Galaktionov Y.K., Efimov V.M. (2003) Variability of morpho-physiological indicators and bilateral asymmetry indices depending on phase of population density dynamics. In: Ravkin Y.S. (ed.) Realization of morphological diversity in natural mammalian populations. Novosibirsk: SB RAS, p. 125-130. (in Russian)

$$
-125-
$$


19. Gennadis G. (1858) Textbook of Regional Anatomy. 1st Edn., Athens: Antoniadis Publisher, p. 270-271.

20. Geodakian V.A. (1991) The evolutionary theory of sex. Priroda (8): 60-69 (in Russian)

21. Geschwind D.H., Miller B.L., DeCarli C., Carmelli D. (2002) Heritability of lobar brain volumes in twins supports genetic models of cerebral laterality and handedness. PNAS 99(5): 3176-3181.

22. Graham J.H., Freeman D.C., Emlen J.M., Leame L.J., Kiesler J.A. (1998) Directional asymmetry and the measurement of developmental instability. Biol. J. Linn. Soc. 64: 1-16.

23. Graham J.H., Shimizu K., Emlen J.M., Freeman D.C., Merkel J. (2003) Growth model and the expected distribution of fluctuating asymmetry. Biol. J. Linn. Soc. 80: 57-65.

24. Hlusko L.J, Sage R.D., Mahaney M.C. (2011). Modularity in the mammalian dentition: Mice and monkeys share a common dental genetic architecture. J. Exp. Zool. B Mol. Dev. Evol. 316(1): $21-49$.

25. Idelman S. (1978) The structure of the mammalian adrenal cortex. In: Jones I.C., Henderson I.W. (eds.) General, comparative and clinical endocrinology of the adrenal cortex. London: Academic Press, p. 1-199.

26. Kharlamova A.V., Trut L.N., Chase K., Kukekova A.V., Lark K.G. (2010) Directional asymmetry in the limbs, skull and pelvis of the silver fox (V.vulpes). J. Morph. 271(12): 1501-1508.

27. Kovaleva V.Y., Faleev V.I. (1994) Morphological variability of Microtus oeconomus (Rodentia, Cricetidae) in different temperature conditions. Zool. Zh. 73(9): 139-145. (in Russian)

28. Kovaleva V.Y., Pozdnyakov A.A., Efimov V.M. (2002) Investigation of variability structure of root vole (Microtus oeconomus Pallas) molar morphotypes using bilateral asymmetry. Zool. Zh. 81(1): 111-117. (in Russian)

29. Larina N.I., Lapshov V.A. (1972) On methods for distinguishing age groups in some voles. In: Physiological and population ecology of animals, vol. 2(4). Saratov: Saratov Univ., p. 92-97. (in Russian)

30. Leung B., Forbes M.R., Houle D. (2000) Fluctuating asymmetry as a bioindicator of stress: comparing efficacy of analyses involving multiple traits. American Naturalist 155(1): 101-115.

31. Levin M., Johnson R.L., Stern C.D., Kuehn M. Tabin C. (1995) A molecular pathway determining left-right asymmetry in chick embryogenesis. Cell 82: 803-814.

32. Levin M., Palmer A.R. (2007) Left-right patterning from the inside out: widespread evidence for intracellular control. BioEssays 29: 271-287.

33. Litvinov Y.N., Abramov S.A., Kovaleva V.Y., Krivopalov A.V., Novikov E.A., Chechulin A.I. (2007) Structural-temporal organization of a rodent community in the Teletskaya taiga, Altai Mountains. Rus. J. Ecol. 38(6): 444-449.

34. Lopez-Gracia M.L., Ros M.A. (2007) Left-right asymmetry in vertebrate development. Adv. Anat. Embryol. Cell Biol. 188: 1-121.

35. Lowe L.A., Supp D.M., Sampath K., Yokoyama T., Wright C.V., Potter S.S., Overbeek P., Kuehn M.R. (1996) Conserved left-right asymmetry of nodal expression and alterations in murine situs inversus. Nature 381: 158-161.

36. Meno C., Shimono A., Saijoh Y., Yashiro K., Mochida K., Ohishi S., Noji S., Kondoh H., Hamada H. (1998) Lefty-1 is required for left-right determination as a regulator of lefty-2 and nodal. Cell 94: 287-297. 
37. Merilä J., Björklund M. (1995) Fluctuating asymmetry and measurement error. Systematic Biol. 44(11): 97-101.

38. Mittwoch U. (1979) Lateral asymmetry of kidney weights in different populations of wild mice. Biol. J. Linn. Soc. 11: 295-300.

39. Mittwoch U. (2008) Different gene expressions on the left and the right: a genotype/phenotype mismatch in need. Ann. Hum. Genet. 72(1): 2-9.

40. Palmer A.R. (1994) Fluctuating asymmetry analysis: a primer. In: Markow T., ed. Developmental instability: its origins and evolutionary implications. Dordrecht: Kluwer Academic Publishers, p. 335-364.

41. Palmer A.R. (1996) From symmetry to asymmetry: phylogenetic patterns of asymmetry variation in animals and their evolutionary significance. PNAS 93: 14279-14286.

42. Palmer A.R. (2009) Animal asymmetry. Curr. Biol. 19(12): 473-477.

43. Palmer A.R. Strobeck C. (1986) Fluctuating asymmetry: measurement, analysis, patterns. Annu. Rev. Ecol. Syst. 17: 391-421.

44. Palmer A.R., Strobeck C. (1992) Fluctuating asymmetry as a measure of developmental stability: implications of non-normal distributions and power of statistical tests. Acta Zool. Fenn. 191: 55-70.

45. Palmer A.R., Strobeck C. (2003) Fluctuating asymmetry studies revisited. In: Polak M., ed. Developmental instability: causes and consequences. Oxford: Oxford University Press, p. 279-319.

46. Pande B.S., Singh I. (1971) One-sided dominance in the upper limbs of human fetuses as evidenced by asymmetry in muscle and bone weight. J. Anat. 109: 457-459.

47. Parsons P.A. (1992) Fluctuating asymmetry: a biological monitor of environmental and genomic stress. Heredity 68: 361-364.

48. Polly P.D., Killick L., Ruddy M. (2011) Using left-right asymmetry to estimate non-genetic variation in vole teeth (Arvicolinae, Muridae, Rodentia). Palaeontologia electronica 14(3, 41A): 1-12.

49. Pozdnyakov A.A. (1993) Morphotypical variability of molars in meadow voles of the "maximoviczi" group (Rodentia, Arvicolidae, Microtus): an attempt of quantitative statistical analysis. Zool. Zh. 72(11): 114-125. (in Russian).

50. Pozdnyakov A.A. (2005) The structure of the grey voles M3 morphological variability (Microtus Schrank, 1798). In: Abramson N.I., Averianov A.O., eds. Systematics, paleontology and phylogeny of rodents. Proc. Zool. Inst. RAS, vol. 306. St. Petersburg: Zool. Inst. RAS, p. 102-115. (in Russian)

51. Pozdnyakov A.A. (2010) Morphological Diversity: characteristics, structure, analysis. In: Bolshakov V.N., ed. Animal communities and populations: ecological and morphological analysis. Proc. Inst. Syst. Ecol. SB RAS, vol. 46. Novosibirsk-Moscow: KMK Press, p. 133-157. (in Russian)

52. Pozdnyakov A.A. (2011) The structure of morphological variability (with the masticatory surface morphotypes of the lower first molar in the voles as an example). Biol. Bull. Rev. 1(5): 471-481 (in Russian)

53. Shiratori H., Hamada H. (2006) The left-right axis in the mouse: from origin to morphology. Development 133: 2095-2104.

54. Siegal M., Bergman A. (2002) Waddington's canalization revisited: Developmental stability and evolution. PNAS 99: 10528-10532. 
55. Singh I. (1971) One-sided dominance in the limbs of rabbits and frogs, as evidenced by asymmetry in bone weight. J. Anat. 109: 271-275.

56. Stige L.C., David B., Alibert P. (2006) On hidden heterogeneity in directional asymmetry - can systematic bias be avoided? J. Evol. Biol. 19(2): 492-499.

57. Tarkhanov I.R. (1879) Psychomotor centres and their development in human and animals. St. Petersburg: L.F.Panteleev, 168 p. (in Russian)

58. Trut L.N., Prasolova L.A., Kharlamova A.V., Plyusnina I.Z. (2002) Directional left-sided asymmetry of adrenals in experimentally domesticated animals. B. Exp. Biol. Med. 133(5): 506509. (in Russian)

59. Van Dongen S. (2006) Fluctuating asymmetry and developmental instability in evolutionary biology: past, present and future. J Evol. 19(6): 1727-1743

60. Vasil'ev A.G. (2009) Phenogenetic variability and population meronomy. Zh. Obsh. Biol. 70(3): 195-209 (in Russian)

61. Vasil'ev A.G., Faleev V.I., Galaktionov Yu.K., et al. (2004) Realization of the morphological diversity in natural populations of mammals. Novosibirsk: SB RAS, 232 p. (in Russian)

62. Vasil'eva I. (1999) Epigenetic divergence of Asian high-mountain voles of the subgenus Aschizomys from southern and north-eastern Siberia. Folia Zool. 48(Suppl. 1): 105-114.

63. Waddington C.H. (1942) Canalization of development and the inheritance of acquired characters. Nature 150: 563-565.

64. Wood W.B. (1997) Left-right asymmetry in animal development. Ann. Rev. Cell Dev. Biol. 13: $53-82$.

65. Zahn J.M., Poosala S., Owen A.B., et al. (2007) AGEMAP: A gene expression database for aging in mice. PLoS Genet. 3: 201.

66. Zakharov V.M. (2003) Linking developmental stability and environmental stress: a whole organism approach. In: Polak M., ed. Developmental instability: causes and consequences. Oxford: Oxford University Press, p. 402-414.

67. Zakharov V.M., Graham J.H. (1992) Developmental stability in natural populations. Acta Zool. Fenn. 191: 7-30. 


\title{
Направленная асимметрия \\ морфологических признаков \\ в течение постнатального онтогенеза \\ у полевки-экономки Microtus oeconomus Pall. \\ (Rodentia, Cricetidae)
}

\author{
В.Ю. Ковалева ${ }^{a}$, \\ В.М. Ефимов ${ }^{\text {а, }, \mathbf{b},}$, Ю.Н. Литвинов ${ }^{\mathrm{a}}$ \\ ${ }^{a}$ Институт систематики и экологии животных СО РАН, \\ Россия 630091, Новосибирск, ул. Фрунзе, 11 \\ ${ }^{6}$ Институт иуитологии и генетики СО РАН, \\ Россия 630090, Новосибирск, Лаврентьева, 10 \\ ${ }^{6}$ Томский государственныий университет, \\ Россия, 634050, Томск, пр. Ленина, 36
}

\begin{abstract}
Проанализирован материал по изменчивости билатеральных морфологических признаков полевки-экономки Microtus оесопотиs, собранный в течение 25 лет (1982-1992, 1994-2005, 2009, 2010). Выявлена направленная асимметрия (НА) морфотипов коренных зубов, веса надпочечников и почек, а также длины задней лапы. Показано, что НА может формироваться как на ранних, так и на поздних стадиях онтогенеза и, по-видимому, имеет четкую генетическую детерминачию. Кроме того, НА каждого метрического признака имеет свою собственную онтогенетическую траекторию, которая не зависит от факторов среды и динамики численности популяиии. В период полового созревания происходит нарастание НА всех метрических признаков, предположительно связанное с нарастанием напряженности прочессов развития. Показано, что половой диморфизм НА формируется на поздних стадиях онтогенеза, что хорошо согласуется с эволючионной теорией пола В.А. Геодакяна. Эволючионное значение НА заключается в повышении адаптивных возможностей как отдельного организма, так и всей популяции. Онтогенетический подход кисследованию морфофункииональных асимметрий у животных открывает новые возможности для исследования эволюиионных прочессов.
\end{abstract}

Ключевые слова: Microtus оесопотия, направленная асимметрия, морфотипы зубов, вес почек и надпочечников, длина лап, условия среды, динамика численности. 